\title{
A UNIVERSALIDADE DOS DIREITOS HUMANOS NO MUNDO MUÇULMANO*
}

\author{
Hidemberg AlVES DA FROTA**
}

RESUMEN: Este artículo trata de las polémicas contemporáneas referentes a los derechos humanos en el entorno islamita. Analiza la repercusión en la comunidad islámica de la Declaración Universal de los Derechos Humanos y del derecho internacional de los derechos humanos, introducidas en la Declaración del Cairo de los Derechos Humanos en Islam del 1990. Examina la libertad religiosa en los Estados de mayoría musulmana. Propone el federalismo comunitario como modo de concretar los derechos humanos en los países de mayoría islámica marcadas por los conflictos étnico-religiosos.

ABSTRACT: This article studies the contemporary controversies concerning human rights in the Islamic world, examines the repercussion in the Islamic community of the Universal Declaration of Human Rights and of the International Human Rights Law (represented by the 1990 Cairo Declaration on Human Rights in Islam), analyses religious freedom in States of Muslim majority and proposes communitarian federalism as way to promote human rights in countries of Islamic majority marked by the ethnic-religious conflicts.

RÉSUMÉ: Cet' article verse sur les polemiques contemporaines sur les droits de l'hômme dans les milieux islamique. Ce lui- ci analyse les repercutions de la declaration Universel des droits d'hômme et droit international des droits de l'hômme integré dans la declaration du Cair sur les droits humains sur les comunautés islamique de 1990. L'article examine les libertés religieuses dans les Etats en majorité musulmane et propose le federalisme comunautaire pour assuré la protection des droits de l'hômme dan les pays en majorité musulmane.

* Dedico este artigo ao prof. J. M. Othon Sidou, pelas entusiasmadas lições de Direito Comparado, pela firme convicção de que o Direito possui princípios gerais universais e por defender a unicidade jurídica universal.

** Bacharel em Direito pelo Centro Universitário de Ensino Superior do Amazonas. 
SUMARIO: I. Introdução. II. O debate em torno do discurso universalista da Declaração Universal dos Direitos Humanos. III. Os antecedentes da Declaração Universal dos Direitos Humanos e da Declaração do Cairo sobre os Direitos Humanos no Islã. IV. O cotejo entre a Declaração Universal dos Direitos Humanos e a Declaração do Cairo sobre os Direitos Humanos no Islã. V. A liberdade de religião no direito constitucional dos Estados de maioria muçulmana. VI. A opção do federalismo comunitário. VII. Conclusão. VIII. Referências bibliográficas.

\section{INTRODUÇÃO}

Este texto esquadrinha questões essenciais envolvendo os direitos humanos no mundo islâmico da atualidade.

Perscrutam-se os aspectos favoráveis e desfavoráveis à eficácia da Declaração Universal dos Direitos Humanos, de 1948, na comunidade islâmica internacional, discutindo-se, ainda, a legitimidade no mundo muçulmano da proposta universalista da DUDH e seus pontos de convergência e divergência com a cultura islamita.

Coteja-se o conteúdo dessa Declaração da ONU com o teor da Declaração do Cairo sobre os Direitos Humanos no Islã, de 1990, além de se comparar o contexto histórico no qual ambas floresceram e se destrinçarem as fontes jurídicas que inspiraram a elaboração dos atos internacionais em testilha.

Analisa-se o respeito à liberdade de religião e correlatas nos 44 Estados nacionais de maioria islamita, ao se estudar o disposto em suas respectivas ordens constitucionais, inclusive o feitio religioso ou laico de tais aparelhos estatais.

E se propõe o federalismo comunitário como meio de nações de maioria islâmica vincadas por históricos embates de intolerância étnico-religiosa se transformarem em países mais arejados para a promoção dos direitos humanos e a reconciliação nacional. 


\section{O DEBATE EM TORNO DO DISCURSO \\ UNIVERSALISTA DA DECLARAÇÃO UNIVERSAL DOS DIREITOS HUMANOS}

Adotada e proclamada pela Resolução no. 217 A (III) da Assembléia Geral das Nações Unidas em 10 de dezembro de 1948, a Declaração Universal dos Direitos Humanos ${ }^{1}$ - DUDH — tem sua legitimidade questionada no mundo muçulmano, nomeadamente a partir da Revolução Islâmica do Irã em 1979, que derrubou a monarquia pró-Ocidente do Xá Reza Pahlevi e instaurou República islâmica com contornos de teocracia de orientação xiita. ${ }^{2}$

Membros mais conservadores da comunidade muçulmana mundial passaram a pôr em xeque de forma mais vigorosa a "validade transcultural"3 de normas contidas na DUDH que ressoam princípios sedimentados no Direito ocidental, todavia estranhos ao Direito muçulmano (Shari'a) ${ }^{4}$ e à tradição islamita, a começar pela liberdade religiosa $\left(\right.$ art. 18) ${ }^{5}$ — que implica a separação entre o Estado e o clero, autoridade secular e religiosa- e pela liberdade de matrimônio (art. 16). ${ }^{6} \mathrm{O}$ exercício de tais liberdades concederia ao ser humano grau de discricionariedade pessoal blasfemo na ótica do Alcorão ${ }^{7}$ e o discurso da universalidade dos direitos humanos à moda ocidental teria como substrato a ideologia materialista do capitalismo globalizado. ${ }^{8}$

Não se trata de posicionamento uníssono no mundo islâmico. Em países norte-africanos integrados à economia global e com classe média considerável, a opinião pública se revela mais aberta a valores ocidentais. ${ }^{9}$ Setores relevantes da sociedade egípcia, por exemplo, tendem a en-

1 Organização das Nações Unidas. Declaração Universal dos Direitos Humanos (1948). Disponível em: http://www.mj.gov.br. Acesso em: 17 set. 2004.

2 Ignatieff, Michael, "The attack on human rights", Foreign Affairs, New York, vol. 80, n 6, nov.-dec. 2001, p. 103.

3 Ibidem, tradução nossa.

4 Serajzadeh, Seyed Hossein, "Islam and crime: the moral community of muslims", Journal of Arabic and Islamic Studies, Bergen, vol. 4, jan. 2001-dec. 2002, p. 121.

5 Ignatieff, Michael, op. cit., p. 103.

6 Organização das Nações Unidas. Declaração Universal dos Direitos Humanos (1948). Disponível em: http://www.mj.gov.br. Acesso em: 17 set. 2004.

7 Ignatieff, Michael, op. cit., p. 104.

8 Ibidem, p. 111.

9 Ibidem, p. 104. 
xergar com relativa parcimônia o direito feminino ao divórcio. ${ }^{10}$ Nada obstante, no Sudeste Asiático nações muçulmanas com economias de mercado - a exemplo da Malásia- repelem os direitos humanos à moda ocidental em nome da primazia dos interesses da família e da coletividade sobre o materialismo individualista. ${ }^{11}$

Em contraponto, avulta-se nova maneira de vislumbrar a universalidade da Declaração Universal dos Direitos Humanos: embora não goze de aceitação universal, traz em seu bojo direitos universais, que têm como destinatários precípuos os hipossuficientes, aqueles cuja esfera de autonomia individual se vê tolhida por poderosas autoridades estatais, tribais, religiosas e familiares. ${ }^{12}$ Em todo o globo os direitos humanos à moda ocidental ofereceriam meios de se harmonizarem os interesses sociais e individuais com o fito de que aqueles não aniquilem estes. ${ }^{13}$

Não representariam adesão à civilização ocidental e sim a indispensável proteção da integridade pessoal ante excessos do comportamento alheio, inclusive do corpo social (v. g., clamor das mulheres do meio rural paquistanês contra o incendeio de esposas desobedientes), e a melhor integração do ser humano em sua sociedade (e. g., reclamos de mulheres afegãs a organismos internacionais, em prol de haver no Afeganistão à época do regime talibã a possibilidade das mulheres conjugarem o culto às tradições locais com o acesso a serviços profissionalizados de educação e saúde). ${ }^{14}$

A reverência aos direitos humanos irradiados pela DUDH significaria proporcionar vazão aos anseios da população posta na base da pirâmide social ${ }^{15}$ de influir na cultura e nos rumos da sociedade. ${ }^{16}$

Ainda em contra-argumento, recorda-se a militância em benefício dos direitos humanos à moda ocidental feita por organizações internacionais não-governamentais (ONGs) contra interesses de vultosas empresas multinacionais, a exemplo das ONGs que lutam pelo respeito aos direitos trabalhistas de empregados da Nike e da Royal Dutch/Shell em países subdesenvolvidos. ${ }^{17}$

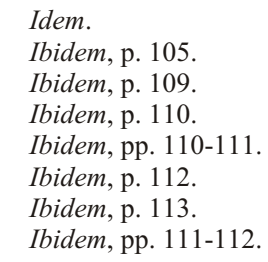




\section{OS ANTECEDENTES DA DECLARAÇÃO UNIVERSAL DOS DiREITOS HUMANOS E DA DECLARAÇÃO DO CAIRO SOBRE OS DIREITOS HUMANOS NO ISLÃ}

Após a Segunda Guerra Mundial a Declaração Universal dos Direitos Humanos da ONU, de 1948, recendeu na cena internacional a promoção dos direitos individuais (civis e políticos) herdados do constitucionalismo ocidental da alvorada do Estado Liberal de Direito, que no final do século XVIII, na esteira das Revoluções Americana, de 1776, e Francesa, de 1789, gerou diplomas constitucionais antológicos (respectivamente, a Constituição dos Estados Unidos, de 1787, e a Declaração dos Direitos do Homem e do Cidadão, de 1789). ${ }^{18}$ Também regurgitou o contributo do parlamentarismo britânico, inserto na Magna Carta, de 1215, e na Carta de Direitos (Bill of Rights), de 1689 ("documentos de natureza materialmente constitucional"). ${ }^{19}$ Seguiu, ainda, os passos dos movimentos missionários oitocentistas antiescravagistas e pró-sufrágio universal. $^{20}$

Dentre as apontadas raízes históricas da DUDH, enfatizam-se dois legados de suma importância:

1. Da Constituição estadunidense e da Declaração Francesa dos Direitos Humanos, em face de ambas aclararem que "todos os homens são seres humanos" 21 e fazem jus a direitos políticos. ${ }^{22}$ Examinando-se Emendas à Carta Constitucional dos EUA, sublinha-se seja a extensão a todos os seres humanos do devido processo legal (Emenda V), seja a proibição de escravidão (Emenda XIII, seção 1, 1a. parte) e de obstar-se o direito a voto com base em critérios raciais (Emenda XV, seção 1). No Diploma Maior da Revolução Francesa, ressalta-se a concepção de que todos os homens tanto nascem (e devem ser) livres, quanto possuem direitos iguais (art. 1o., 1a. parte), inclusive políticos, em se tratando de cidadãos (art. 6o.);

18 Morrison, Heidi, "Beyond universalism”, Muslim World Journal of Human Rights, Berkeley, vol. 1, no. 1, jan.-dec. 2004, pp. 1-2.

19 Pinheiro, Luís Felipe Valerim, "O devido processo legal e o processo administrativo", Fórum Administrativo: Direito Público, Belo Horizonte, ano 2, n. 20, out. 2002, p. 1324.

20 Morrison, Heidi, op. cit., p. 1.

21 Ibidem, p. 2, tradução nossa.

22 Ibidem, p. 2. 
2. E dos missionários cristãos do século XIX, pioneiros em materializarem a filosofia da solidariedade a estranhos e em cultivarem a idéia de que todos temos alma e, em conseqüência, todos somos humanos. ${ }^{23}$

Emergindo em uma ordem internacional sob os escombros da recém-terminada Segunda Guerra Mundial, a Declaração Universal dos Direitos Humanos da ONU almejou robustecer o Direito Natural, de maneira a precaver a humanidade contra experiências similares ao do nazifascismo, em que o Direito Positivo agasalhou arbitrariedades do Poder Público. ${ }^{24}$ O Código Penal italiano de 1930 ("Código Rocco") considerava "delito contra a personalidade do Estado injuriar 'a honra ou o prestígio do chefe de governo' (art. 282)". ${ }^{25}$ Em 1935 o princípio da legalidade foi extirpado do Código Penal alemão, cujo art. 2o. passou a prescrever a punição de quem "comete um ato que a lei declara punível ou que, conforme a idéia fundamental de uma lei penal e ao sentimento do povo, merece ser punido". ${ }^{26}$

Já a Declaração do Cairo sobre os Direitos Humanos no Islã, de 1990, foi precedida pela desilusão de setores da comunidade muçulmana com o Ocidente e pelo ressurgimento dos movimentos islâmicos conservadores, ambos resultados quer da busca pela preservação da identidade islamita em meio aos embates ideológicos da Guerra Fria entre os Estados Unidos e a União Soviética, quer da derrota árabe (do Egito, Jordânia e Síria) para Israel na Guerra Árabe-Israelita de 1967, a nominada Guerra dos Seis Dias ou Guerra de Junho (ao cabo da qual Israel assumiu o controle da Península do Sinai, da Faixa de Gaza, das Colinas do Golã, da Cisjordânia e anexou Jerusalém Oriental), ${ }^{27}$ cujos reflexos jurídicos, antes de se fazerem presentes na Declaração do Cairo, de 1990, manifestaram-se no aparecimento da Constituição da República Islâmica do Irã, de 1979, e da Declaração Universal Islâmica dos Direitos Humanos -DUIDH, de 1981-.28

23 Morrison, Heidi, op. cit., p. 2.

24 Idem.

25 Zaffaroni, Eugenio Raúl y Pierangeli, José Henrique, Manual de direito penal brasileiro: parte geral, 3a. ed., São Paulo, RT, 2001, p. 333.

26 Ibidem, p. 335.

27 Heritage, Andrew y Cavanagh, Louise, Enciclopédia Geográfica Universal, Rio de Janeiro, Globo, 1995, v. 5, pp. 306-307; Preece, Warren E. (ed.), The New Encyclopaedia Britannica, 15th ed., Chicago, Macropaedia, 1980, v. 9, pp. 774-775.

28 Morrison, Heidi, op. cit., p. 13. 
A atual Constituição iraniana fundeou a República Islâmica no senso de justiça corânico (art. 1o.), submeteu o Direito Legislado aos comandos de Deus (art. 2o. (1), (2) e (4)) e sujeitou todo o ordenamento jurídico irânico aos critérios do Islã, inclusive matérias civil, penal, financeira, econômica, administrativa, cultural, militar e política (art. 4o.).

Apesar de ter reconhecido como minorias religiosas apenas as comunidades zoroástrica, judaica e cristã do Irã (art. 13), ${ }^{29}$ a Constituição iraniana de 1979, em relação aos não-muçulmanos que se abstêm de atuarem contra o Islã e a República Islâmica do Irã, positivou o dever desta e de todos os muçulmanos tanto os tratarem de acordo com as normas éticas e os princípios de justiça e eqüidade islâmicos, quanto respeitarem seus direitos humanos (art. 14). ${ }^{30}$

Estipulou a inviolabilidade da dignidade, da vida, da propriedade, dos direitos, da residência e da ocupação do indivíduo, salvo nos casos previstos em lei (art. 22). Proibiu investigações sobre as crenças do ser humano ou punições em função de se esposar determinada crença (art. 23). Restringiu a liberdade de expressão da imprensa se, nos termos da lei, evidencia-se detrimentosa aos princípios fundamentais do Islã e aos direitos do público (art. 24).

Dentre as normas entalhadas na hodierna Constituição do Irã, sobressaem estas quatro:

1. O princípio comunitário (art. 8o.), ${ }^{31}$ extraído do início do versículo 71, da 9a. Surata, do Alcorão, segundo o qual "os fiéis e as fiéis são protetores uns dos outros; recomendam o bem, proíbem o ilícito", 32 além de consubstanciar dever universal e recíproco, aplica-se ao povo e ao governo e às relações estabelecidas entre ambos;

2. O princípio da independência (art. 9o.), a indissociar a liberdade, a independência, a unidade e a integridade territorial do Irã, constitui norma obrigatória para o governo e os cidadãos iranianos e veda qualquer indivíduo, grupo ou autoridade de, a pretexto de exercer dada liberdade, maltratar a independência (política, cultural, econômica e militar) e a integridade territorial do Irã, como também proíbe qualquer autoridade de

29 Idem.

30 Idem.

31 Idem.

32 Alcorão. Disponível em: http://www.culturabrasil.org/alcorao.htm. Acesso em: 30 abr. 2005. 
ab-rogar liberdades legítimas, a fim de garantir a independência e a integridade territorial nacional;

3. O princípio da família (art. 10), que avista na família a unidade fundamental da sociedade islâmica e comete às leis, regulamentos e pertinentes programas a finalidade de facilitarem a formação da família e salvaguardarem sua santidade e a estabilidade das relações familiares, com base nas normas do Islã;

4. O princípio da unidade do Islã (art. 11), abaliza o versículo 92, da 21a. Surata ${ }^{33}$ — "Esta vossa comunidade é a comunidade única e Eu sou o vosso Senhor. Adorai-Me, portanto (e a nenhum outro)!"-, preconiza a existência de uma única nação para todos os muçulmanos e divisa o múnus da República Islâmica do Irã formular políticas gerais voltadas a cultivar a amizade e a unidade entre todos os islâmicos e se empenhar na construção da unidade política, econômica e cultural no mundo islamita.

Assinado por Salem Azzam, à época Secretário-Geral do Conselho Islâmico, o prefácio da Declaração Islâmica Universal dos Direitos Humanos, de 1981, percebe que em Deus reside o pólo irradiador dos direitos humanos, a conferirem honra e dignidade à humanidade e a eliminarem exploração, opressão e injustiça. ${ }^{34}$

A Declaração Universal Islâmica dos Direitos Humanos, cujo campo de incidência abarca todos os homens e mulheres da comunidade islâmica mundial (Ummah Islamia), reverbera os direitos humanos revelados por Deus por meio do Direito muçulmano (Shari'a) e os deveres a eles correspondentes, dilucidam as Notas Explicativas do mencionado ato internacional, em seus itens 1 e $2 .{ }^{35}$

Do ponto de vista da DUIDH os direitos humanos se condicionam aos contornos delineados pelo Shari'a e deste dimanam o fundamento para a condenação criminal do indivíduo. ${ }^{36}$ o tratamento justo e generoso a ser conferido aos trabalhadores, ${ }^{37} \mathrm{o}$ direito e o dever de se socorrer dos remédios legais para a defesa contra lesões ou danos pessoais injustificados, ${ }^{38}$ os temperamentos ao direito à vida, à integridade física e à liberda2005.

34 Conselho Islâmico. Universal Islamic Declaration of Human Rights. Disponível em: http://www.alhewar.com. Acesso em: 26 abr. 2005.

35 Idem.

36 Art. 5o., alínea “d”.

37 Art. 17.

38 Art. 4o., alínea "b", 2a. parte. 
de lato $\operatorname{sensu}^{39}$ (gênero no qual se encartam as liberdades física, cultural, econômica e política; ${ }^{40}$ incluindo-se a liberdade de crença, pensamento, expressão; ${ }^{41}$ informação; ${ }^{42}$ residência e locomoção ${ }^{43}$ e a moldura a que se circunscrevem os direitos à subsistência, ${ }^{44}$ ao exercício de atividades econômicas, ${ }^{45}$ à distribuição de renda ${ }^{46}$ ao casamento, a constituir família e a criar filhos em sintonia com sua religião, tradição e cultura ${ }^{47}$ além dos direitos da esposa viver na residência onde mora o marido, ${ }^{48}$ ser municiada de meios de subsistência não-inferiores ao do marido (inclusive enquanto aguarda o divórcio),$^{49}$ ao divórcio, ${ }^{50}$ à herança ${ }^{51}$ e à confidencialidade das informações do conhecimento do marido ou ex-marido, cuja revelação seja deletéria aos interesses da esposa ou ex-esposa (dever equivalente possui a consorte ou ex-consorte em relação ao esposo ou ex-esposo). ${ }^{52}$

A DUIDH reverencia os interesses comunitários, ao abranger seja o direito e dever de cada indivíduo lutar pelo respeito aos direitos de quaisquer outras pessoas e da comunidade (art. 4o., alínea "c"), seja a proibição das atividades econômicas e dos meios de produção contrariarem os interesses da comunidade (art. 15, alíneas "e" e "g").

Por outro lado, a DUIDH ressalta o dever da comunidade quer fomentar condições para o pleno desenvolvimento da personalidade humana (art. 14, alínea "b"), quer assistir pessoas temporária ou permanentemente incapacitadas (art. 18, 2a. parte).

No tocante ao direito à (e ao dever de) resistência, a Declaração Universal Islâmica dos Direitos Humanos agasalha não só o direito a (e o dever de) desobedecer a comandos afrontosos ao Direito muçulmano (art. 4o., "e"), como também o direito a (e o dever de) protestar e lutar contra

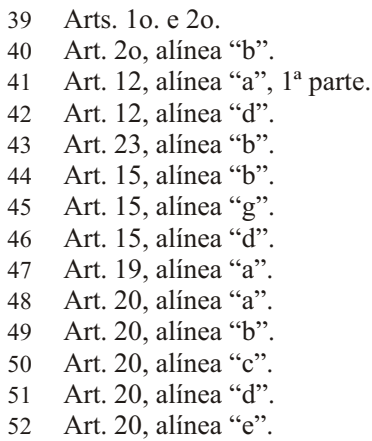


a opressão, mesmo se emanada de altas autoridades estatais (art. 12, alínea "c").

\section{O COTEJO ENTRE A DECLARAÇÃO UNIVERSAL DOS DiREITOS HUMANOS E A DECLARAÇÃO DO CAIRO SOBRE OS DIREITOS HUMANOS NO ISLÃ}

\section{Direito à igualdade e ao devido processo legal}

A Declaração Universal dos Direitos Humanos, de 1948, da Assembléia Geral das Nações Unidas, clarifica que todas as pessoas nascem livres e iguais em dignidade e direitos, ${ }^{53}$ têm capacidade para gozar os direitos e as liberdades nela estabelecidos, sem quaisquer discriminações (v. g., raça, cor, sexo, língua, religião, opinião, origem nacional ou social, riqueza e nascimento). ${ }^{54}$

Emoldurada pelo Direito muçulmano, ${ }^{55}$ à luz da qual deve ser interpretada, ${ }^{56}$ a Declaração do Cairo sobre Direitos Humanos no Islã, de 1990, da 19a. Conferência Islâmica dos Ministros das Relações Exteriores, estatui que todos os seres humanos formam família única, subordinada a Alá e descendente de Adão, ${ }^{57}$ que todos os homens são iguais em termos de dignidade humana, direitos e obrigações básicos, sem quaisquer discriminações (e. g., raça, cor, língua, crença, sexo, religião, filiação política e status social), ${ }^{58}$ que a religião verdadeira (o islamismo) assegura o alcance de tal dignidade essencial e da integração da humanidade $^{59}$ e que os seres humanos mais amados por Alá são aqueles mais benéficos a Seus súditos e ninguém é superior a ninguém, salvo quanto ao grau de piedade e boas ações.

A Declaração da ONU de 1948 reconhece a todos o direito de serem, em todos os lugares, pessoas perante a lei, ${ }^{60}$ receberem tributos nacionais aptos a remediar menoscabo a direitos fundamentais (tenham estes espe-

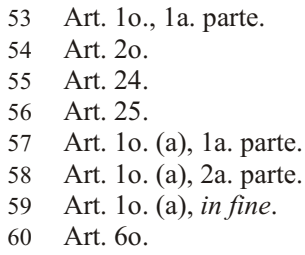


que constitucional ou apenas legal $)^{61}$ e auferirem da lei proteção e tratamento igualitário (sem distinção alguma), ${ }^{62} \mathrm{em}$ sede de devido processo legal material e formal, o que importa seja efetuarem-se de maneira não-arbitrária prisões, ${ }^{63}$ exílios, ${ }^{64}$ desapropriações ${ }^{65}$ e mitigações ao direito à nacionalidade, ${ }^{66}$ seja haver audiências justas e públicas perante tribunais independentes e imparciais, ${ }^{67}$ respeitados o estado (ou a presunção) de inocência e a ampla defesa, ${ }^{68}$ vedados quer imputar-se delito imprevisto no direito nacional ou internacional, quer impor-se pena mais forte do que aquela que, no momento da prática, era aplicável ao ato delituoso, assim como tortura, tratamento ou castigo cruel, desumano ou degradante. ${ }^{69}$

A Declaração Islâmica de 1990 assegura a todos, sem distinções entre soberano e súdito, a igualdade perante a lei ${ }^{70} \mathrm{e}$ no acesso à Justiça, ${ }^{71} \mathrm{a}$ responsabilidade essencialmente pessoal, ${ }^{72}$ o estado (ou a presunção) de inocência e o julgamento célere (franqueadas as garantias de defesa) ${ }^{73}$ e a proibição de crimes e punições desprovidas de abrigado no Shari' $a,{ }^{74}$ de sanções e restrições à liberdade carentes de legitimidade, de maus-tratos físicos e psíquicos, de experimentos médicos e científicos sem consentimento ou prejudiciais à saúde ou à vida e de medidas estatais executórias de caráter emergencial a incidirem em quaisquer das aludidas vedações. ${ }^{75}$ Proscreve, ainda, todas as modalidades de seqüestro ${ }^{76}$ e a desapropriação ilegal, ${ }^{77}$ desprovida do sinete do interesse público e da pronta e justa indenização. ${ }^{78}$

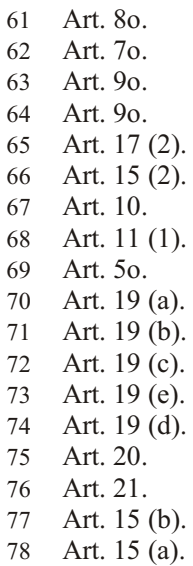




\section{Direito às liberdades civis, à vida privada e à vida familiar}

A Declaração da ONU de 1948 se posiciona contra a escravidão, o tráfico escravagista e a servidão. ${ }^{79}$ Confere a todas as pessoas o direito à vida. ${ }^{80}$ à liberdade, ${ }^{81}$ à segurança pessoal ${ }^{82}$ e à nacionalidade. ${ }^{83}$ Protege a vida privada de intrusões e a honra de ataques. ${ }^{84}$ Alberga a liberdade de locomoção e residência dentro das fronteiras estatais, ${ }^{85} \mathrm{o}$ direito de asilo (salvo em caso da prática de crimes comuns ou infringência a propósitos e princípios das Nações Unidas) ${ }^{86}$ e de deixar (e regressar a) qualquer país. ${ }^{87}$ Acolhe as liberdades de pensamento, ${ }^{88}$ consciência, ${ }^{89}$ religião, ${ }^{90}$ opinião, ${ }^{91}$ expressão, ${ }^{92}$ reunião ${ }^{93}$ e associação pacíficas ${ }^{94}$ (no entanto, é contra obrigar-se alguém a fazer parte de uma associação). ${ }^{95}$ Preceitua o direito ao matrimônio e de fundar família, mediante livre escolha dos nubentes e direitos iguais entre homens e mulheres, sem quaisquer discriminações. ${ }^{96}$

A Declaração Islâmica de 1990 encerra em suas fileiras o direito à vida de todos os seres humanos, vê nele dom divino a ser salvaguardado pelos indivíduos, sociedades e Estados (salvo as exceções contidas no Shari'a), ${ }^{97}$ proíbe o emprego de meios a propiciarem o genocídio da humanidade, ${ }^{98}$ preconiza tanto a preservação da vida durante o tempo permitido por Alá, ${ }^{99}$ quanto a proteção da integridade física pelo Estado

$\begin{array}{ll}79 & \text { Art. 4o. } \\ 80 & \text { Art. 3o. } \\ 81 & \text { Idem. } \\ 82 & \text { Idem. } \\ 83 & \text { Art. 15 (1). } \\ 84 & \text { Art. 12. } \\ 85 & \text { Art. 13 (1). } \\ 86 & \text { Art. 14. } \\ 87 & \text { Art. 13(2). } \\ 88 & \text { Art. 18. } \\ 89 & \text { Idem. } \\ 90 & \text { Idem. } \\ 91 & \text { Art. 19. } \\ 92 & \text { Idem. } \\ 93 & \text { Art. 20(1). } \\ 94 & \text { Idem. } \\ 95 & \text { Art. 20(2). } \\ 96 & \text { Art. 16. } \\ 97 & \text { Art. 2o. (a). } \\ 98 & \text { Art. 2o. (b). } \\ 99 & \text { Art. 20. (c). }\end{array}$


(dispensável apenas se contar com a chancela do Direito muçulmano), ${ }^{100}$ corrobora o direito à segurança do indivíduo e de seus dependentes ${ }^{101} \mathrm{e}$, dentre os direitos post-mortem, inclui a proteção da honra do de cujus e do seu cadáver (e do local de sepultamento) contra profanações. ${ }^{102}$

A Declaração do Cairo incorpora normas de Direito Internacional Humanitário. Exclui do alvo de conflitos armados a população não-beligerante (v.g., homens velhos, mulheres e crianças). A feridos e doentes, apregoa o direito a tratamento médico. A prisioneiros de guerra, o direito a alimentos, abrigo e vestimenta. Aos mortos, o direito de não ter o cadáver mutilado ou desmembrado. Propugna a troca de prisioneiros de guerra e visitas ou reuniões de familiares separados por circunstâncias de guerra. ${ }^{103}$ Ainda sobre conflitos armados, repele o corte de árvores e a destruição de plantações e granjas, edificações e instalações civis. ${ }^{104}$

$\mathrm{Na}$ ótica dessa Declaração Islâmica, todos os seres humanos nascem livres. A ninguém é dado o direito de escravizar, humilhar, oprimir e explorar. Submissão só existe a Alá. ${ }^{105}$ Insere o colonialismo entre as mais maléficas formas de escravidão. Àqueles objetos do colonialismo reconhece o direito de liberdade e autodeterminação. Tem como dever dos povos de todos os Estados apoiarem a luta dos povos colonizados contra qualquer espécie de ocupação. ${ }^{106}$ Abona o direito à livre residência e movimento dentre e fora do país do indivíduo. ${ }^{107}$ Para a Declaração do Cairo o Estado a quem se pede asilo possui o dever de concedê-lo, exceto se disser respeito a crime capitulado no Shari'a. ${ }^{108}$

A Declaração do Cairo sobre os Direitos Humanos no Islã abraça o exercício seja do direito de propriedade ${ }^{109}$ (desde que não prejudique o proprietário, outrem e a sociedade), ${ }^{110}$ seja do direito à vida privada segura, ${ }^{111}$ vendo na esfera privada o espaço onde se preza pela inviolabili-

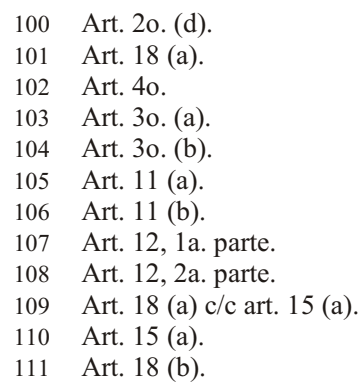


dade do lar, ${ }^{112}$ dos assuntos privados, ${ }^{113}$ da honra ${ }^{114}$ e da propriedade,, 15 amparando-se a família, ${ }^{116}$ os relacionamentos privados ${ }^{117}$ e a liberdade religiosa. ${ }^{118}$ Vislumbra na família a fundação da sociedade, enxerga no casamento o alicerce da família e imuniza o exercício do direito a matrimônio de discriminações de raça, cor ou nacionalidade. ${ }^{119}$ Exige que a sociedade e o Estado removam todos os obstáculos ao casamento, facilitem-no, salvaguardem a família e seu bem-estar. ${ }^{120}$ Equipara a mulher ao homem em dignidade, comete ao sexo feminino direitos, deveres e estatuto civil próprios, independência financeira, direito a nome e à linhagem. ${ }^{121}$ Incumbe ao marido o dever de mantença e bem-estar familiar. ${ }^{122}$

A DCDHI sustenta a liberdade de opinião alinhada aos princípios islâmicos ${ }^{123}$ e o direito de defender o correto, fazer o bem e alertar contra o errado e o mal, observadas as normas do Direito muçulmano. ${ }^{124}$

\section{Direito às liberdades políticas e à democracia}

A Declaração Universal dos Direitos Humanos, de 1948, permite a toda pessoa tomar parte no governo de seu país por meio da democracia direta ou representativa, ${ }^{125}$ eleger seus representantes por meio de pleitos periódicos e legítimos (por sufrágio universal, voto secreto ou processo equivalente, assegurada a liberdade de voto) ${ }^{126}$ e ter acesso ao serviço público de sua nação. ${ }^{127}$

A Declaração do Cairo sobre os Direitos Humanos no Islã, de 1990, proporciona a todos o direito à elegibilidade (se perdida ou prejudicada, o eleitor pode se fazer representar por curador), em seus direitos e deve-

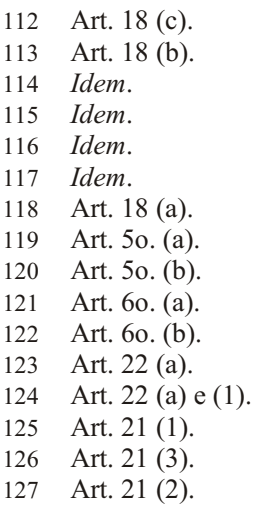


res, ${ }^{128} \mathrm{o}$ direito à informação (caso não viole a dignidade dos Profetas e valores morais e éticos, não seja maléfica à sociedade, nem enfraqueça sua fé, muito menos instigue discriminação racial e ódios nacionais ou doutrinários), ${ }^{129} \mathrm{o}$ direito de participar direita ou indiretamente na administração pública do seu país e de assumir cargos públicos (em conformidade com o Shari'a) $)^{130}$ e o dever de qualquer autoridade se abster de praticar abusos ou exploração maliciosa. ${ }^{131}$

\section{Direitos sociais, econômicos e culturais e o direito ao meio ambiente sadio}

A Declaração Universal dos Direitos Humanos, de 1948, entende que toda pessoa tem direito a padrão de vida capaz de assegurar a si e a sua família saúde e bem-estar (inclusive alimentação, vestuário, habitação, cuidados médicos e os serviços sociais indispensáveis) e direito à segurança (em caso de desemprego, doença, invalidez, viuvez, velhice ou outros casos de perda dos meios de subsistência em circunstâncias fora de seu controle). ${ }^{132}$

Para a Declaração de 1948 a maternidade e a infância têm direito a cuidados e assistência especiais, de forma que todas as crianças, nascidas dentro ou fora do matrimônio, gozem da mesma proteção social, ${ }^{133}$ que toda pessoa possua direito à instrução (gratuita, pelo menos nos graus elementares e fundamentais, obrigatória em nível elementar, acessível a todos no ensino técnico-profissional e superior, este baseado no mérito). ${ }^{134}$

Conforme dispõe a DUDH, a instrução será orientada para o pleno desenvolvimento da personalidade humana e o fortalecimento do respeito aos direitos humanos e às liberdades fundamentais, promovendo-se a compreensão, a tolerância e a amizade entre todas as nações e grupos raciais ou religiosos, a coadjuvar as atividades das Nações Unidas em prol 
da manutenção da paz. ${ }^{135}$ Os pais passam a ter direito à escolha do gênero de instrução a ser ministrado a seus filhos. ${ }^{136}$

No sentir da DUDH, toda pessoa tem o direito de participar livremente da vida cultural da comunidade, de fruir as artes e de participar do processo científico e dele se beneficiar. ${ }^{137} \mathrm{o}$ direito à proteção dos interesses morais e materiais decorrentes de qualquer produção científica, literária ou artística da qual seja autor ${ }^{138}$ e o direito a uma ordem social e internacional em que os direitos e liberdades estabelecidos na presente Declaração possam ser plenamente realizados. ${ }^{139}$

A Declaração do Cairo sobre os Direitos Humanos no Islã, de 1990, encarrega a sociedade e o Estado de viabilizar a busca pelo conhecimento. ${ }^{140}$ Ao aparelho estatal cabe fomentar a educação e o interesse humano pela religião islâmica e pelos segredos do universo. ${ }^{141}$ Estimula a família, as instituições educacionais e os meios de comunicação divulgarem, em moldes integrados e equilibrados, o conhecimento religioso e temporal. ${ }^{142}$ Repulsa todas as formas de se pressionar o ser humano ou se explorar a pobreza ou ignorância humana com vistas a convencê-lo a mudar de religião ou aderir ao ateísmo. ${ }^{143}$

A DCDHI aventa a assistência médico-hospitalar e a educação (inclusive respeitante à higiene e à moral) das crianças, bem como o auxílio especial ao feto e à sua genitora. ${ }^{144} \mathrm{~A}$ educação deve ser apropriada aos interesses e ao futuro da criança, em sintonia com os valores éticos e os princípios do Shari'a. ${ }^{145}$ Os direitos dos pais e dos familiares sobre as crianças se norteiam pelos dogmas do Direito muçulmano. ${ }^{146}$

A Declaração do Cairo respalda o direito ao sustento legítimo (escoimado de usura, monopolização, fraude ou danos ao indivíduo que o exercita e aos demais), ${ }^{147} \mathrm{o}$ direito à assistência médica e social (permitida a 
ajuda da sociedade e do Estado, na proporção dos recursos disponíveis $)^{148}$ e estes direitos trabalhistas fundamentais: ${ }^{149}$

1. A sociedade e o Estado devem assegurar o direito de trabalho a todas as pessoas aptas a trabalhar;

2. Livre escolha do trabalho que melhor serve aos interesses do trabalhador e da sociedade;

3. Benefícios da segurança do trabalho e da seguridade social;

4. Desenvolver o trabalho na medida da capacidade do trabalhador, sem trabalho compulsório, explorativo ou danoso;

5. Concessão de promoções merecidas, bem como pagamento célere de salários justos e retribuição pecuniária correspondente aos dias de feriados.

A par disso, elenca o dever seja do trabalhador ser dedicado e meticuloso, ${ }^{150}$ seja do Estado intervir na resolução dos dissídios trabalhistas. ${ }^{151}$

Calha ao Estado catalisar condições de vida que contemplem as necessidades do ser humano e de seus dependentes (inclusive no que concerne à alimentação, vestimenta, moradia, educação e assistência médica). ${ }^{152}$

Em relação aos direitos culturais a Declaração do Cairo apregoa que todos tenham direito aos frutos do seu trabalho autoral (científico, literário, artístico ou técnico), garantida a proteção dos seus interesses morais e materiais a ele relacionados, obedecidas as balizas do Direito muçulmano. ${ }^{153}$

O dever social e estatal de se assegurar o meio ambiente sadio corresponde à obrigação da sociedade e do Estado proporcionarem ambiências depuradas de vícios e corrupção moral e adequadas ao desenvolvimento ético saudável do ser humano. ${ }^{154}$ 


\section{A LIBERDADE DE RELIGIÃO NO DIREITO CONSTITUCIONAL DOS ESTADOS DE MAIORIA MUÇULMANA}

\section{O perfil dos Estados de maioria muçulmana}

Estima-se existirem no globo atualmente 1,3 bilhões de muçulmanos. ${ }^{155}$ Cerca de 1 bilhão desse contingente de islamitas vive em 44 países de maioria muçulmana, ${ }^{156}$ adiante especificados em conformidade com a região do planeta considerada:

1. Oriente Médio e África do Norte: ${ }^{157}$ Argélia, Barein, Egito, Irã, Iraque, ${ }^{158}$ Jordânia, Kuwait, Líbano, Líbia, Marrocos, Omã, Qatar, Arábia Saudita, Síria, Tunísia, Emirados Árabes Unidos (EAU) e Iêmen;

2. Ásia Meridional:159 Afeganistão, Bangladesh, Maldivas e Paquistão;

3. Ásia Oriental: ${ }^{160}$ Brunei, Indonésia e Malásia;

4. África: ${ }^{161}$ Burkina Faso, Chade, Camarões, Djibouti, Gâmbia, Guiné, Mali, Mauritânia, Níger, Senegal, Serra Leoa, Somália' ${ }^{162}$ e Sudão;

5. Europa e Eurásia: ${ }^{163}$ Albânia, Azerbaijão, Quirguistão, Tadjiquistão, Turquia, Turcomenistão e Uzbequistão.

Compulsando-se o Direito Constitucional Positivo desses 44 Estados nacionais de maioria muçulmana, verifica-se que a metade declara o Islã a religião oficial. ${ }^{164}$ Dessa parcela, 10 se consideram Estados islâmicos. ${ }^{165}$ Afora esses 22 Estados de religião oficial muçulmana, sobra a ou-

155 Stahnke, Tad y Blitt, Robert C., The Religion-State Relationship and the Right to Freedom of Religion or Belief: A Comparative Textual Analysis of the Constitutions of Predominantly Muslim Coutries, Washington D. C., U. S. Commission on International Religious Freedom, 2005, p. 6.

156 Idem.

157 Ibidem, pp. 29-37.

158 Cita-se neste trabalho o Diploma Constitucional provisório do Iraque sob ocupação norte-americana, a Lei Administrativa Transitória (Transitional Administrative Law-TAL). Cfr. ibidem, p. 1 .

159 Ibidem, pp. 38-42.

160 Ibidem, pp. 43-44.

161 Ibidem, pp. 45-49.

162 A Somália se encontra sem Constituição. Cfr. ibidem, p. 48.

163 Ibidem, pp. 50-52.

164 Ibidem, p. 7.

165 Idem. 
tra metade, composta por 11 Estados cujas Constituições não especificam se são seculares ou islâmicos e 11 Estados seculares. ${ }^{166}$

Encontram-se 602,5 milhões de islâmicos (58\% da população muçulmana mundial) em 22 Estados de religião oficial muçulmana (Afeganistão, Barein, Brunei, Irã, Maldivas, Mauritânia, Omã, Paquistão, Arábia Saudita, Iêmen, Argélia, Bangladesh, Egito, Iraque, Jordânia, Kuwait, Líbia, Malásia, Marrocos, Qatar, Tunísia e EAU). ${ }^{167}$

Situam-se 285,5 milhões de islamitas (28\%) em 10 Estados que, além de terem como religião oficial o islamismo, expressamente se reputam Estados muçulmanos (Afeganistão, Barein, Brunei, Irã, Maldivas, Mauritânia, Omã, Paquistão, Arábia Saudita e Iêmen). ${ }^{168}$

Localizam-se 287,5 milhões (28,5\%) de muçulmanos em 11 Estados que não possuem dispositivos constitucionais a esclarecerem se são ordens estatais seculares ou muçulmanas (Albânia, Líbano, Síria, Indonésia, Camarões, Djibouti, Gâmbia, Serra Leoa, Somália, Sudão e Uzbequistão). ${ }^{169}$

Por fim, restam 140 milhões $(13,5 \%)$ de islâmicos, circunscritos a 11 Estados seculares (Burkina Fasso, Chade, Guiné, Mali, Níger, Senegal, Azerbaijão, Quirguistão, Tadjiquistão, Turquia e Turcomenistão). ${ }^{170}$

166 Idem

167 Constituições do Afeganistão, art. 2o.; do Barein, art. 2o.; do Brunei, art. 3o.(1); do Irã, art. 12; de Maldivas, art. 7o.; da Mauritânia, art. 5o.; de Omã, art. 2o.; do Paquistão, art. 20.; da Arábia Saudita, art. 1o.; do Iêmen, art. 2o.; da Argélia, art. 2o.; de Bangladesh, art. 2o.; do Egito, art. 2o.; do Iraque, art. 7o. (A); da Jordânia, art. 2o.; do Kuwait, art. 2o.; da Líbia, art. 2o.; da Malásia, art. 3o.(1); do Marrocos, art. 6o.; do Qatar, art. 1o.; da Tunísia, art. 1o.; e do EAU, art. 7o.. Cfr. ibidem, pp. 29-52.

168 Constituições do Afeganistão, art. 1o.; do Barein, art.1o.; do Brunei, art. 3o.(2); do Irã, art. 1o.; das Maldivas, art. 1o.; da Mauritânia, art. 1o.; de Omã, art. 1o.; do Paquistão, art. 1o. (1); da Arábia Saudita, art. 1o.; e do Iêmen, art. 1o. Cfr. ibidem, pp. 7, 29-52.

169 Idem.

170 Constituições da Burkina Fasso, art. 31; do Chade, art. 1o.; da Guiné, art. 1o.; do Mali, art. 25; do Níger, art. 4o. c/c 136; do Senegal, art. 1o.; do Azerbaijão, art. 7o. c/c 18 (I) e (III); do Quirguistão, art. 1o.(1) c/c art. 8o. (3) e (4); do Tadjiquistão, arts. 1o., 8o. e 100; da Turquia, art. 20. c/c 174; e do Turcomenistão, art. 1o.. Cfr. ibidem, pp. 29-52; Stahnke, Tad y Blitt, Robert C., op. cit., p. 7 . 


\section{A adequação aos padrões internacionais mínimos de liberdade religiosa}

Na presente análise adotam-se os "padrões mínimos"171 de liberdade de religião (ou crença) e culto acolhidos pelo Direito Internacional dos Direitos Humanos de matriz ocidental, típicos das democracias ocidentais e esboçados quer pela Declaração Universal dos Direitos Humanos, de 1948 (art. 18) -DUDH—, quer pelo Pacto Internacional sobre os Direitos Civis e Políticos (art. 18), de 1966 -PIDCP-.

Consoante tais parâmetros, as liberdades de religião, crença e culto devem se estender a todos os indivíduos, independente de sua religião ou crença, os quais podem exercitá-las pelo ensino, pela prática, pelo culto e pela observância, isolada ou coletivamente, em público ou em particular, sem discriminações, favorecimentos ou coações, sendo admissíveis temperamentos a esse direito civil apenas se respeitadas as balizas do Direito Internacional dos Direitos Humanos (de matriz ocidental). ${ }^{172}$

O contraste entre os critérios traçados pelo DUDH (art. 18), pelo PIDCP (art. 18) e pelo Direito Constitucional Positivo de 44 Estados nacionais de maioria islâmica conduz à percepção de que 21 desses países se adequam ao padrão internacional de liberdade de religião (ou crença) e culto (Iraque, Bangladesh, Paquistão, Indonésia, Malásia, Chade, Djibouti, Gâmbia, Guiné, Mali, Níger, Senegal, Serra Leoa, Sudão, Albânia, Azerbaijão, Quirguistão, Tadjiquistão, Turquia, Turcomenistão e Uzbequistão). ${ }^{173}$

Dentre os 21 Estados favoráveis à liberdade de religião e culto, 10 desfrutam de explícitas garantias constitucionais contra a coerção religiosa (Iraque, Bangladesh, Paquistão, Malásia, Serra Leoa, Sudão, Albânia, Azerbaijão, Turquia e Uzbequistão). ${ }^{174}$

171 Ibidem, p. 12.

172 Stahnke, Tad y Blitt, Robert C., op. cit., p. 12.

173 Constituições do Iraque (arts. 7 (A), Bangladesh (arts. 39 e 41), Paquistão (arts. 20 a 22), Indonésia (arts. 28E (1), (2) e (3), 29 (1) e (2) e 28I (1)), Malásia (arts. 11 (1), (2), (3), (4) e (5) e 12 (2) e (3)), Chade (arts. 27 e 54), Djibouti (arts. 25 (1), (b) e (c) e (4), 32 e 212 (3), Gâmbia (arts. 25 (1), (b) e (c), (4), 32 e 212 (3)), Guiné (arts. $7^{\circ}$ e 14), Mali (arts. $4^{\circ}$ e 18), Níger (arts. $8^{\circ}, 14$ e 16), Senegal (arts. $8^{\circ}$ e 24), Serra Leoa (art. 24 (1), (2), (3), (4), (5), (a) e (b)), Sudão (arts. 24 e 27), Albânia (arts. 20 e 24), Azerbaijão (arts. 48 e 71), Quirguistão (arts. 16 e 82), Tadjiquistão (art. 26), Turquia (arts. 14 e 24), Turcomenistão (art. 11) e Uzbequistão (arts. 31 e 61). Cfr. ibidem, pp. 15, 53-74.

174 Constituições do Iraque (arts. 7 (A), 13 (F) e 15 (C)), Bangladesh (arts. 39 e 41), Paquistão (arts. 20 a 22), Malásia (arts. 11 (1), (2), (3), (4) e (5) e 12 (2) e (3)), Serra Leoa (art. 24 (1), (2), (3), 
Contudo, desses 44 Estados-nações, 22 possuem disposições constitucionais aquém da garantia da liberdade religião (ou crença) ou seus comandos constitucionais se circunscrevem à proteção da liberdade de culto (Argélia, Barein, Egito, Irã, Jordânia, Kuwait, Líbano, Líbia, Marrocos, Omã, Qatar, Arábia Saudita, Síria, Tunísia, EAU, Iêmen, Afeganistão, Brunei, Maldivas, Camarões, Mauritânia e Somália). ${ }^{175}$

Ademais, 12 não estão providos de normas constitucionais que positivem direitos individuais correlatos ao da liberdade religiosa ou possuem normas constitucionais a restringirem o exercício de tais direitos por determinado(s) grupo(s) (Barein, Egito, Irã, Jordânia, Líbano, Líbia, Omã, Síria, EAU, Afeganistão, Maldivas e Burkina Fasso). ${ }^{176}$

Por último, 15 limitam as liberdades de religião, crença e culto além do permitido pelo Direito Internacional dos Direitos Humanos de matriz ocidental (Barein, Irã, Jordânia, Kuwait, Líbia, Omã, EAU, Afeganistão, Brunei, Maldivas, Djibouti, Gâmbia, Níger, Serra Leoa e Turquia). ${ }^{177}$

\section{A OPÇÃO DO FEDERALISMO COMUNITÁRIO}

Nos Estados de maioria muçulmana e árabe convém levar em conta a possibilidade de se adotar a forma federativa de Estado como meio de se apaziguarem conflitos étnico-religiosos e com isso melhor se homenagearem os direitos humanos, cujo respeito se mostra árduo em ambientes marcados pelo enraizado ódio étnico e lancinante antagonismo religioso.

(4), (5), (a) e (b)), Sudão (arts. 24 e 27), Albânia (arts. 20 e 24), Azerbaijão (arts. 48 e 71), Turquia (arts. 14 e 24) e Uzbequistão (arts. 31 e 61). Cfr. ibidem, pp. 15, 53-74.

175 Constituição da Argélia (art. 36), Barein (art. 22), Egito (art. 46), Irã (arts. 12 a 14 c/c arts. 23 e 26), Jordânia (arts. 14 e 19), Kuwait (art. 35), Líbano (arts. 9o. a 10), Líbia (art. 2o.), Marrocos (art. 6o.), Omã (art. 28), Qatar (art. 50), Arábia Saudita (arts. 9o. e 26), Síria (art. 35 (1) e (2)), Tunísia (art. 5o.), EAU (art. 32), Iêmen (arts. 41 e 51), Afeganistão (arts. 2o., 45 e 54), Brunei (art. 3o. (1)), Maldivas (art. 25), Camarões (preâmbulo) e Mauritânia. (Somália se encontra sem Constituição.) Cfr. ibidem, pp. 15, 53-74.

176 Constituições de Barein (art. 22), Egito (art. 46), Irã (arts. 12 a 14 c/c arts. 23 e 26), Jordânia (arts. 14 e 19), Líbano (arts. 9o. a 10), Líbia (art. 2o.), Omã (art. 28), Síria (art. 35 (1) e (2)), EAU (art. 32), Afeganistão (arts. 2o., 45 e 54), Maldivas (art. 25) e Burkina Fasso (art. 7o.). Cfr. ibidem, pp. $15,53-74$.

177 Constituições do Barein (art. 22), Irã (arts. 12 a 14 c/c arts. 23 e 26), Jordânia (arts. 14 e 19), Kuwait (art. 35), Líbia (art. 2o.), Omã (art. 28), EAU (art. 32), Afeganistão (arts. 2o., 45 e 54), Brunei (art. 3 (1)), Maldivas (art. 25), Djibouti (arts. 25 (1), (b), (c) e (4), 32 e 212 (3), Gâmbia (arts. 25 (1), (b), (c) e (4), 32 e 212 (3)), Níger (arts. 8o., 14 e 23), Serra Leoa (art. 24 (1), (2), (3), (4) e (5), (a) e (b)) e Turquia (arts. 14 e 24). Cfr. ibidem, pp. 15, 53-74. 
Em vez do federalismo tradicional, de cunho geográfico, calçado na divisão do território estatal em unidades regionais com autogoverno (reflexo da autonomia política, normativa, financeira e administrativa) e repartidas por fronteiras fictícias, o federalismo ora indicado possui caráter comunitário, centrado em fornecer às comunidades étnico-religiosas papéis nitidamente demarcados, de modo a não haver entre elas conflitos de competência (ou atribuições) e guerras civis pelo controle do Poder Público, sem separá-las em territórios como se fossem compartimentos estanques, uma vez que a partição geográfica de comunidades étnico-religiosas poderia redundar em apartheids e olvidaria o fato de que muitas vezes elas compartilham o mesmo espaço físico (cidade ou região). ${ }^{178}$

Exemplo de Estado de maioria muçulmana apropriado ao federalismo comunitário é o Iraque, onde a população se triparte em árabes xiitas (60\%), árabes sunitas $(20 \%)$ e curdos sunitas $(20 \%)$, existem históricas contendas entre quer árabes e curdos, quer árabes sunitas e xiitas, e não há como se traçar uma linha geográfica razoável, a apartar em territórios distintos árabes sunitas e xiitas. ${ }^{179}$

Entretanto, dentre os Estados de maioria muçulmana, o Líbano se sobressai por alojar os primeiros precedentes jurídicos para o federalismo comunitário. ${ }^{180}$ Reformada em 1927, 1928, 1947 e 1990, a Constituição libanesa, de 1926, art. 24 (1), alínea "a", ${ }^{181}$ preceitua número igual de assentos para muçulmanos e cristãos na Câmara dos Deputados (o Parlamento libanês é unicameral). ${ }^{182}$ O Pacto Nacional de 1948 (não-escrito ${ }^{183}$ firmou o costume seguido até hoje: o Presidente da República é cristão maronita; o primeiro-ministro, muçulmano sunita; e o Presidente da Câmara dos Deputados, muçulmano xiita. ${ }^{184}$

178 Mallat, Chibli, "Federalism in the Middle East and Europe", Case Western Reserve Journal of International Law, Cleveland, vol. 35, no. 1, set.-dec. 2003, p. 12.

179 Ibidem, p. 11.

180 Mallat, Chibli, op. cit., pp. 12 y 13.

181 Líbano. Lebanon constitution. Disponível em: http://www.oefre.unibe.ch/law/icl/le00000_. html. Acesso em: 5 mai. 2005.

182 Art. 16.

183 Jelloun, Mohammed Ben, What's consociational patriotism?: from Lebanon to Iraq. Disponível em: http://swans.com/library/art11/jelloun2.html Acesso em: 5 mai. 2005.

184 Mallat, Chibli, op. cit., pp. 12 y 13. 


\section{CONCLUSÃO}

1. Conquanto a Declaração Universal dos Direitos Humanos, de 1948, da Assembléia Geral das Nações Unidas, careça de legitimidade plena por reverberar o Direito ocidental e destoar de tradições seculares do Direito muçulmano (a exemplo do exercício da liberdade de matrimônio e da separação entre Estado e clero), traz em seu bojo direitos universais que têm como destinatários precípuos os seres humanos cuja esfera de autonomia individual se vê tolhida por poderosas autoridades estatais, tribais, religiosas e familiares.

2. A Declaração Universal dos Direitos Humanos, de 1948, influenciada pela Constituição dos Estados Unidos, de 1787, pela Declaração dos Direitos do Homem e do Cidadão, de 1789, pela Magna Carta, de 1215, pelo Bill of Rights, de 1689, e pelos movimentos missionários oitocentistas antiescravagistas e pró-sufrágio universal, vem a lume no Pós-Segunda Guerra Mundial, visando a revigorar os direitos naturais como barreiras às normas do Direito Positivo contrárias aos direitos humanos e favoráveis a regimes ditatoriais ou totalitários.

3. Já a Declaração do Cairo sobre os Direitos Humanos no Islã, de 1990, da $19^{a}$ Conferência Islâmica dos Ministros das Relações Exteriores, antecedida pela Constituição da República Islâmica do Irã, de 1979, e pela Declaração Universal Islâmica dos Direitos Humanos, de 1981, ressoa a desilusão de setores da comunidade muçulmana com o Ocidente e o ressurgimento dos movimentos islâmicos conservadores, ambos resultados quer da busca pela preservação da identidade islamita em meio aos embates ideológicos da Guerra Fria entre os Estados Unidos e a União Soviética, quer da derrota árabe (do Egito, Jordânia e Síria) para Israel na Guerra Árabe-Israelita de 1967.

4. A Declaração do Cairo sobre os Direitos Humanos no Islã continua o esforço antes iniciado pela Declaração Universal Islâmica dos Direitos Humanos de ajustar ao Direito muçulmano os direitos humanos historicamente afinados com os tratados e as Constituições de matriz ocidental, em particular no tocante ao direito à igualdade e ao devido processo legal, ao direito às liberdades civis, à vida privada e à vida familiar, ao direito às liberdades políticas e à democracia, aos direitos sociais, econômicos e culturais e ao direito ao meio ambiente sadio.

5. Embora a Declaração do Cairo sobre os Direitos Humanos no Islã se aproxime da Declaração Universal dos Direitos Humanos quando alo- 
ja direitos de caráter civil, político-democrático, social, econômico e cultural, distancia-se dela ao submeter os direitos humanos à moldura teológica do Direito muçulmano e vai além da Declaração da ONU de 1948 ao catalogar o direito ao meio ambiente sadio.

6. Averiguando-se o Direito Constitucional Positivo dos 44 Estados nacionais de maioria muçulmana, nota-se que metade declara o Islã a religião oficial (10 desses 44 se consideram Estados islâmicos) e a outra metade se divide em 11 Estados seculares e 11 Estados cujas Constituições não especificam se são seculares ou islâmicos.

7. Dos 44 Estados de maioria muçulmana, 21 contemplam o padrão internacional de liberdade de religião (ou crença) e culto. Desse grupo de 21, 10 Estados desfrutam de explícitas garantias constitucionais contra a coerção religiosa. Por outro lado, desses 44 Estados-nações, 22 possuem disposições constitucionais aquém da garantia da liberdade religião (ou crença) ou seus comandos constitucionais se circunscrevem à proteção da liberdade de culto; 12 estão providos de normas constitucionais que não positivam direitos individuais correlatos ao da liberdade de religião ou possuem normas constitucionais a restringirem o exercício de tais direitos por determinado(s) grupo(s); 15 limitam as liberdades de religião, crença e culto além do permitido pelo Direito Internacional dos Direitos Humanos de matriz ocidental.

8. Nos Estados de maioria muçulmana e árabe nos quais setores expressivos da sociedade nutrem entre si ódio étnico e antagonismo religioso, o federalismo comunitário ressai como mecanismo a arrefecer tais animosidades e assim pavimentar o caminho para a maior difusão da reverência aos direitos humanos, ao fornecer às comunidades étnico-religiosas papéis nitidamente demarcados, de forma a não haver entre elas conflitos de competência (ou atribuições) e guerras civis pelo controle do Poder Público, sem separá-las em territórios como se fossem compartimentos estanques, uma vez que a partição geográfica de comunidades étnico-religiosas poderia redundar em apartheids e olvidaria o fato de que muitas vezes elas compartilham o mesmo espaço físico (cidade ou região).

\section{REFERÊNCIAS BIBLIOGRÁFICAS}

AlCORÃO. Disponível em: http://www.culturabrasil.org/alcorao.htm. Acesso em: 30 abr. 2005. 
19a. Conferência Islâmica de Ministros das Relações Exteriores, The Cairo Declaration on Human Rights in Islam. Disponível em: http://www.humanrights.harvard.edu. Acesso em: 26 abr. 2005.

Conselho Islâmico, Universal Islamic Declaration of Human Rights.

Disponível em: http://www.alhewar.com. Acesso em: 26 abr. 2005.

Estados Unidos da América, Constituição dos Estados Unidos da América. Disponível em: http://www.embaixada-americana.org.br. Acesso em: 26 abr. 2005.

FRANÇA, Declaração dos Direitos do Homem e do Cidadão. Disponível em: http://www.direitoshumanos.usp.br. Acesso em: 26 abr. 2005.

Heritage, Andrew y Cavanagh, Louise, Enciclopédia Geográfica Universal, Rio de Janeiro, Globo, 1995, v. 5.

IGNATIEFF, Michael, "The attack on human rights", Foreign Affairs, New York, vol. 80, no. 6, nov.-dec. 2001.

IRÃ, The Constitution of the Islamic Republic of Iran. Disponível em: http://www.oefre.unibe.ch. Acesso em: 26 abr. 2005.

JELLOUN, Mohammed Ben, What's consociational patriotism?: from Lebanon to Iraq. Disponível em: http://swans.com/library/art11/jello un2.html Acesso em: 5 mai. 2005.

Líbano. Lebanon constitution. Disponível em:http://www.oefre.unibe.ch/ law/icl/le00000.html. Acesso em: 5 mai. 2005.

MaLlat, Chibli, "Federalism in the Middle East and Europe", Case Western Reserve Journal of International Law, Cleveland, vol. 35, no. 1, set.-dec. 2003.

MORRISON, Heidi, "Beyond universalism", Muslim World Journal of Human Rights, Berkeley, vol. 1, no. 1, jan.-dec. 2004.

Organização das Nações Unidas, Declaração Universal dos Direitos Humanos (1948), Disponível em: http://www.mj.gov.br. Acesso em: 17 set. 2004.

— - Pacto Internacional sobre os Direitos Civis e Políticos (1966). Disponível em: http://www.dhnet.org.br. Acesso em: 11 out. 2004.

PREECE, Warren E. (ed.), The New Encyclopaedia Britannica, 15th ed., Chicago, Macropaedia, 1980, vol. 9

PINHEIRO, Luís Felipe Valerim, "O devido processo legal e o processo administrativo", Fórum Administrativo, Belo Horizonte, Direito Público, ano 2, no. 20, out. 2002. 
SERAJZADEH, Seyed Hossein, "Islam and crime: the moral community of muslims", Journal of Arabic and Islamic Studies, Bergen, vol. 4, jan. 2001-dec. 2002.

StAHnKe, Tad y BlitT, Robert C. The Religion-State Relationship and the Right to Freedom of Religion or Belief: A Comparative Textual Analysis of the Constitutions of Predominantly Muslim Coutries, Washington D. C., U. S. Commission on International Religious Freedom, 2005.

ZAFFARONI, Eugenio Raúl y PIERANGeli, José Henrique, Manual de direito penal brasileiro, parte geral, 3a. ed., São Paulo, RT, 2001. 